\title{
Calcium regulation of growth and differentiation in Streptococcus pneumoniae
}

\author{
Marie-Claude Trombe, ${ }^{*}$ Corinne Clavé $\dagger$ and Jean-Michel Manias $\ddagger$ \\ Centre de Biochimie et de Génétique Cellulaires du CNRS et Université Paul Sabatier, 118 route de Narbonne, 31062 \\ Toulouse Cédex, France
}

(Received 28 May 1991; revised 2 September 1991; accepted 17 September 1991)

\begin{abstract}
Streptococcus pneumoniae requires $\mathrm{O} \cdot 15 \mathrm{mM}-\mathrm{Ca}^{2+}$ in the medium for optimal growth. Increasing the $\mathrm{Ca}^{2+}$ concentration to $1 \mathrm{mM}$ triggers either a differentiative state, competence for genetic transformation during exponential growth, or partial lysis as soon as the cultures enter stationary phase. Genetic and physiological data both suggest that these responses are under the control of activator(s), excreted in the presence of high $\mathrm{Ca}^{2+}$ concentrations. ${ }^{45} \mathrm{Ca}^{2+}$ transport is also stimulated by the activator(s). The amiloride derivative $2^{\prime}, 4^{\prime}$ dimethylbenzamil (DMB) inhibits ${ }^{45} \mathrm{Ca}^{2+}$ transport and prevents lysis and competence development. This provides evidence in favour of the involvement of $\mathrm{Ca}^{2+}$ transport in competence and culture lysis. On the other hand, addition of DNA to a competent culture prevents lysis of wild-type bacteria while a mutant, defective for DNA uptake, is not protected from lysis by exogenous DNA. An hypothesis is proposed for competence induction as a global metabolic response to $\mathrm{Ca}^{2+}$, under the control of competence factor.
\end{abstract}

\section{Introduction}

Streptococcus pneumoniae is one of the bacterial species that are able to go through a transient differentiative physiological state, competence for genetic transformation. Competent bacteria exhibit new properties with regard to surface antigens (Nava et al., 1963), membrane nuclease activity (Lacks \& Greenberg, 1973; Lacks \& Neuberger, 1975), DNA transport (Lerman \& Tolmach, 1957), recombination and repair (Love \& Yasbin, 1986), expression of a set of specific proteins (Morrison \& Baker, 1979; Raina \& Ravin, 1980) and synthesis of the lipid polymer poly $(\beta$-hydroxybutyrate) (Reusch \& Sadoff, 1983; Clavé et al., 1989). Membrane hyperpolarization (Trombe, 1983), as well as a stimulation of glycolysis associated with an increased ATP pool and a cytoplasmic alkalinization (Lopez et al., 1989), are observed in competent $S$. pneumoniae. A remarkable feature in streptococci is that all these responses are controlled by an excreted protein, competence factor (CF) (Leonard \&

\footnotetext{
- Author for correspondence. Tel. 61335971 ; fax 61335886.

† Present address: Laboratoire de Génétique, Université Bordeaux II, 33405 Talence Cédex, France.

$\ddagger$ Present address: Laboratoire de traitement des eaux, Institut National des Sciences Appliquées, Toulouse, France.

Abbreviations: CF, competence factor; DMB, 2',4'-dimethylbenzamil; HMA, 5-( $N, N^{\prime}$-hexamethylene $)$ amiloride.
}

Cole, 1972; Pakula \& Walczak, 1963; Tomasz \& Hotchkiss, 1964), which probably reacts with a receptor in the cell membrane to activate competence (Ziegler \& Tomasz, 1970).

Competence in $S$. pneumoniae is routinely obtained when cells are grown in $\mathrm{Ca}^{2+}$-rich ( 1 to $1.5 \mathrm{mM}$ ) media. The $\mathrm{Ca}^{2+}$ requirement for growth in prokaryotes is not very well documented. Some evidence now exists for bacterial calmodulin-like proteins (Falah et al., 1988; Fry et al., 1986; Inouye et al., 1983; Swan et al., 1987, 1989), suggesting a regulatory function for $\mathrm{Ca}^{2+}$. On the other hand, $\mathrm{Ca}^{2+}$ circulation is described as an electrochemical process (for a review, see Rosen, 1987) associated with its export involving a $\mathrm{Ca}^{2+}$-ATPase in streptococci (Kobayashi et al., 1978; Ambudkar et al., 1986). In the work presented here, we have addressed the relationship between $\mathrm{Ca}^{2+}$, bacterial growth and induction of the differentiative state, permissive for DNA uptake and genetic transformation, i.e. competence.

\section{Methods}

Strains. The RX derivative Streptococcus pneumoniae $\mathrm{Cp} 1000$ was used as the standard wild-type strain for competence induction and for genetic transformation (Morrison et al., 1984). The required mutations were introduced into the wild-type background by genetic transforma- 


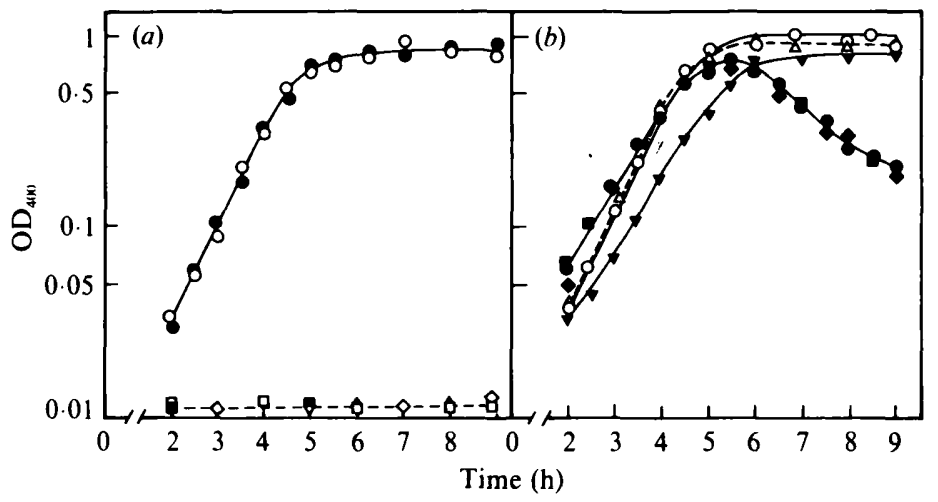

Fig. 1. $\mathrm{Ca}^{2+}$ regulation of growth: effect of amilorides. (a) $\mathrm{Ca}^{2+}$ requirement. The endogenous $\mathrm{Ca}^{2+}$ of the growth media at $\mathrm{pH} 7$ (open symbols) or $\mathrm{pH} 8$ (filled symbols) was chelated with $0 \cdot 2 \mathrm{mM}$-EGTA and $\mathrm{CaCl}_{2}$ was then added to obtain final concentrations of $0.05 \mathrm{~mm}(\diamond, \diamond), 0.1 \mathrm{~mm}(\square, \square)$ or $0.15 \mathrm{~mm}(O$, O). Growth at $37^{\circ} \mathrm{C}$ was then monitored (see Methods). (b) $\mathrm{Ca}^{2+-i n d u c e d ~ l y s i s: ~} \mathrm{pH}$ effect and inhibition by amilorides. Cells were grown in media containing $1.5 \mathrm{mM}-\mathrm{Ca}^{2+}$ at $\mathrm{pH} 7$ (open symbols) or $\mathrm{pH} 8$ (filled symbols). Amiloride or amiloride derivatives were added at time zero. Solid line, wildtype strain : $O$,, no addition; $\square$, plus $5 \mu \mathrm{M}-\mathrm{HMA}$; $\bullet$, plus $5 \mu \mathrm{M}$-amiloride; $\nabla$, plus $5 \mu \mathrm{M}$-DMB. Dashed line, strain $\mathrm{Cpl095}$ grown at $\mathrm{pH} 8(\triangle)$. tion using DNA from the mutant strains. Two rounds of transformation with non-saturating levels of DNA were performed to avoid multiple gene transfer. The mutation in the lyt A gene of strain Cpl095 comes from strain GP95, a derivative of RUP1, which carries an ery insertion in lytA, lytA : :ermC (Tomasz et al., 1988). The mutation in the com locus of strain Cpl 322 was introduced with DNA from strain omega 22, a competence-defective mutant selected after insertional mutagenesis (Morrison et al., 1984). Strain CP1209, which carries the ent-9 mutation, is defective in DNA transport (Morrison et al., 1983; Clavé et al., 1987).

Specific materials. The source of $\left[{ }^{3} \mathrm{H}\right] \mathrm{DNA}$ was the thymidine auxotrophic strain 119 which also carries the rif-23 mutation (Tiraby \& Fox, 1973). Amilorides were provided by Dr E. J. Cragoe, Jr, Nacogdoches, Texas, USA; 2',4'-dimethylbenzamil (DMB) was prepared specifically for this study. The calcium ionophore A23187, EGTA and tripolyphosphate (pentasodium salt) were analytical grade. Salmon sperm DNA and tRNA were from Sigma. Nutrients used for growth media were from Difco. ${ }^{45} \mathrm{CaCl}_{2}$ was from $\mathrm{CEA}$, France.

Growth and competence induction. Growth conditions and media were identical for the wild-type and the mutant strains as described previously (Clavé et al., 1987). Growth was routinely followed by optical density measurements at $\mathbf{4 0 0} \mathrm{nm}$ using a Bausch and Lomb spectrophotometer. The decrease in $\mathrm{OD}_{400}$ was taken as an indicator of culture lysis. For each experiment, a given growth curve was performed in triplicate. The curve presented is thus representative of three independent assays. Briefly, stock cultures were grown at $\mathbf{p H} 7.5$ in a standard medium containing $\left(\mathrm{g}^{-1}\right)$ : $\mathrm{NaCl}, 5$; yeast extract, 1; tryptone, 5; enzymic casein hydrolysate, $10 ;$ glucose, $2 ; \mathrm{K}_{2} \mathrm{HPO}_{4}, 3$. When the culture reached an $\mathrm{OD}_{400}$ of about $\mathbf{0 \cdot 4}$, glycerol (final concn $15 \%, v / v)$ was added and samples were kept frozen at $-80^{\circ} \mathrm{C}$. To obtain precompetent bacteria, samples were thawed, diluted 1 to 100 in transformation medium [standard growth medium enriched with $\mathrm{CaCl}_{2}(1 \mathrm{mM})$ and bovine serum albumin $\left.\left(1 \mathrm{mg} \mathrm{m}^{-1}\right)\right]$ at neutral $\mathrm{pH}$, and grown for $2 \mathrm{~h}$ at $37^{\circ} \mathrm{C}$. Such cultures constituted the 'tester cells'. When shifted to $\mathrm{pH} 7.8$ and incubated at $37^{\circ} \mathrm{C}$, they could develop 'natural' competence in 60 to 120 min or could be activated by CFcontaining extract and develop competence in $20 \mathrm{~min}$. Competence induction could not be observed at $32^{\circ} \mathrm{C}$ but competence expression of pre-induced bacteria was maximal at this temperature.

Activator preparation. CF-containing extracts were supernatants of competent wild-type cultures fractionated with $55 \%$ saturation $\left(\mathrm{NH}_{4}\right)_{2} \mathrm{SO}_{4}$ at $\mathrm{pH} 11$. The pellet dissolved in $10 \mathrm{~mm}-\mathrm{HCl}$ was the source of $\mathrm{CF}$; it was kept frozen at $-80^{\circ} \mathrm{C}$. One $\mathrm{CF}$ unit induces competence of $1 \mathrm{ml}$ of tester cells $\left(2 \times 10^{8}\right.$ c.f.u. $)$ of strain $\mathrm{Cp} 1000$ at $\mathrm{pH} 7$ in $30 \mathrm{~min}$.
Extracts from competent cultures of strain Cp1322 contain no detectable CF activity (Morrison et al., 1984) and were used as controls.

Assay for competence. Competence reporters (Clavé \& Trombe, 1989) were the degradation of extracellular pneumococcal [ $\left.{ }^{3} \mathrm{H}\right] \mathrm{DNA}$ resulting in acid-soluble material, the uptake of $\left[{ }^{3} \mathrm{H}\right] \mathrm{DNA}$ in a DNAase-Iresistant form and genetic transformation for the chromosomal marker rif-23, which confers resistance to $2 \mu \mathrm{g}$ rifampicin $\mathrm{ml}^{-1}$.

Ion transport measurements. Ion transport was assayed using the radioactive isotope ${ }^{45} \mathrm{Ca}^{2+}$. Tester cells were incubated in transformation medium containing the radioactive isotope. CF-containing extract was then added and $1 \mathrm{ml}$ samples were filtered at intervals through $0.45 \mu \mathrm{m}$ Gelman Metricel membranes. After three washes with media containing $0.5 \mathrm{mg} \mathrm{CaCl} \mathrm{ml}^{-1}$, the radioactivity retained on the filters was quantified by liquid scintillation as previously described (Trombe et al., 1984). It was verified that washing with $\mathrm{CaCl}_{2}$ lowered nonspecific adsorption on the filters without significant displacement of intracellular ${ }^{45} \mathrm{Ca}^{2+}$.

\section{Results}

\section{$\mathrm{Ca}^{2+}$ requirement for growth}

The standard growth medium used for $S$. pneumoniae was found to contain $0.2 \mathrm{~mm}$-calcium as measured by flame spectrophotometry. When $\mathrm{Ca}^{2+}$ was chelated with 0.2 mM-EGTA, growth was inhibited. Full growth could be restored by addition of a further $0.15 \mathrm{mM}-\mathrm{CaCl}_{2}$ to medium containing $0.2 \mathrm{mM}-\mathrm{EGTA}$ (Fig. $1 \mathrm{a}$ ). Therefore, $\mathrm{Ca}^{2+}$ is an obligatory cation for growth of $S$. pneumoniae. Similar results were obtained whether the $\mathrm{pH}$ of the medium was 7 or 8 (Fig. $1 a$ ). However, increasing the $\mathrm{Ca}^{2+}$ concentration to $1.5 \mathrm{mM}$ caused precocious lysis of wild type $S$. pneumoniae when the culture reached stationary phase. Culture lysis in high- $\mathrm{Ca}^{2+}$ medium was strongly dependent on the initial $\mathrm{pH}$ of the cultures and did not occur at neutral pH (Fig. 1 b). Strain Cp1095, which caries an insertion in the $l y t A$ gene that encodes the major autolysin (Tomasz et al., 1988), was fully resistant to lysis in alkaline $\mathrm{Ca}^{2+}$-containing medium (Fig. 1 b). LytA must therefore be involved in the $\mathrm{Ca}^{2+}$. triggered lysis. 


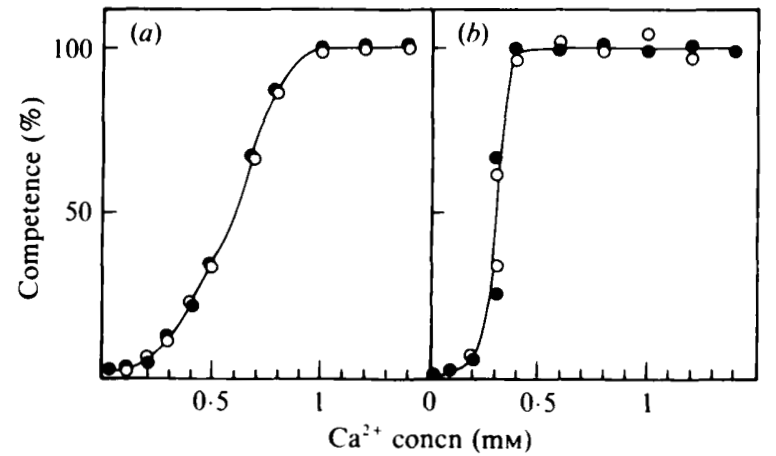

Fig. 2. Specific $\mathrm{Ca}^{2+}$ requirement for competence induction or for competence expression. (a) Induction. Tester cells were incubated in media at $\mathrm{pH} 8$ containing various $\mathrm{Ca}^{2+}$ concentrations with CF-free extracts of strain $\mathrm{Cp} 1322$ (O) or with $0 \cdot 1 \mathrm{CF}$ units $\mathrm{ml}^{-1}$ (O). Competence development was monitored at intervals by assaying the nuclease activity of the cultures using $\left[{ }^{3} \mathrm{H}\right] \mathrm{DNA}\left(1 \mu \mathrm{g} \mathrm{m} l^{-1}\right.$; $10^{5}$ d.p.m. $\mathrm{ml}^{-1}$ ) (see Methods). The highest competence level achieved for each culture is expressed as a percentage of the maximum competence level achieved at a saturating $\mathrm{Ca}^{2+}$ concentration ( $1 \mathrm{mM}$ ). (b) Expression. Bacteria induced to competence in a medium containing $1.5 \mathrm{~mm}-\mathrm{Ca}^{2+}$ were shifted at $32{ }^{\circ} \mathrm{C}$ into media containing various $\mathrm{Ca}^{2+}$ concentrations and $\left[{ }^{3} \mathrm{H}\right] \mathrm{DNA}\left(1 \mu \mathrm{g} \mathrm{ml}^{-1} ; 10^{5}\right.$ d.p.m. $\left.\mathrm{ml}^{-1}\right)$. CF $\left(0 \cdot 1\right.$ units $\left.\mathrm{ml}^{-1}\right)$ was added in one series of samples $(O)$ while the other received CF-free extracts from strain Cpl $322(\mathrm{O})$. After 15 min incubation at $32^{\circ} \mathrm{C}$, the acid-soluble radioactivity was quantified by liquid scintillation counting.

\section{$\mathrm{Ca}^{2+}$ requirement for differentiation: competence development}

In the experimental system used for this study, competence was induced in early exponential phase when the culture was alkaline, as described by Chen \& Morrison (1987). A competence cycle could be divided into two steps: induction, which required $20 \mathrm{~min}$ incubation at $37^{\circ} \mathrm{C}$ in $\mathrm{CF}$-containing medium or 60 to $120 \mathrm{~min}$ in the absence of $\mathrm{CF}$, and expression, where all the properties of the competent bacteria were expressed. The $\mathrm{Ca}^{2+}$ requirement for both steps was determined using $\mathrm{Ca}^{2+}$ titrated media, as described for the experiments shown in Fig. 1. A difference in the $\mathrm{Ca}^{2+}$ requirement for optimal induction ( $1 \mathrm{mM}$ ) (Fig. $2 a$ ) and for optimal expression $(0.4 \mathrm{~mm})$ (Fig. $2 b$ ) suggests a specific requirement at induction. DNA transport is probably the $\mathrm{Ca}^{2+}$ requiring step at the expression stage (Lacks \& Greenberg, 1973; Seto \& Tomasz, 1974, 1976; Lacks, 1977; Clavé et al., 1989; Clavé \& Trombe, 1989). Addition of $\mathrm{CF}$ to the medium did not change the $\mathrm{Ca}^{2+}$ dependence (Fig. 2), nor did the $l y t A$ mutation carried by strain CP1095 (data not shown). Interestingly, from the data presented, the conditions required for competence induction correspond to conditions which cause precocious lysis in the wild-type strain.

\section{CF activation of competence and culture lysis}

In cultures growing at neutral $\mathrm{pH}$, competence develops naturally in the late exponential phase and at high cell density (Chen \& Morrison, 1987). It was possible to induce competence in the early exponential phase, at neutral $\mathrm{pH}$, by the addition of extra $\mathrm{CF}$, above the concentration which induced competence in alkaline cultures (Fig. 3a). Interestingly, precocious lysis in high$\mathrm{Ca}^{2+}$ medium was also obtained at neutral $\mathrm{pH}$ in the presence of CF (Fig. 3b). The com mutant Cp1322, which required high levels of $\mathrm{CF}$ for its activation whatever the $\mathrm{pH}$ used (Fig. 3a), was fully resistant to culture lysis in alkaline medium containing high $\mathrm{Ca}^{2+}$, but lysed if the culture was complemented with CF (Fig. $3 d$ ). The same threshold concentration of $\mathrm{CF}$ was required to induce both competence and lysis (Fig. $3 a, d$ ). The single mutational event carried by the com strain prevents both natural lysis and competence induction. These defects are complemented under the same conditions, i.e. CF addition, suggesting a correlation between competence induction and culture lysis as proposed by Seto \& Tomasz (1975). However, the LytA-null mutant Cp1095, which was refractory to lysis even in high-CF medium (Fig. 3c), exhibited the same CF requirement for competence induction as the wild-type strain (Fig. $3 a$ ), and was fully transformable (data not shown) as already shown for other lyt strains (Sanchez-Puelles et al., 1986; Tomasz et $a l .$, 1988), indicating that LytA is not involved in competence-regulation. The effect of $\mathrm{CF}$ in lowering the growth rate and growth yield of $\mathrm{Cpl} 095$ is noteworthy (Fig. $3 c$ ). This effect was not observed in media with a low $(0.2 \mathrm{mM}) \mathrm{Ca}^{2+}$ concentration (Fig. $3 c$ ). Thus, competence induction might be considered as a response to $\mathrm{Ca}^{2+}$ stress under the control of $\mathrm{CF}$. Another possibility would be that both a competence activator and a lysis activator are released at the same time in competent cultures. In any case, competence and lysis represent two manifestations of the $\mathrm{Ca}^{2+}$ response, regulated by the $\mathrm{pH}$ of the medium and under the control of released factor(s).

\section{Prevention of lysis by exogenous DNA}

In Bacillus subtilis it is proposed that competence is induced in response to a variety of signals including growth stage and nutritional information (for a review, see Dubnau, 1991). Culture-medium titrations showed no variation in glucose and phosphate concentrations during the development of a competence cycle in $S$. pneumoniae (Clavé, 1988). Taking into account the composition of the transformation medium (see Methods), $\mathrm{N}$-starvation seems unlikely. Thus unbalanced growth with regard to $\mathrm{C}, \mathrm{P}$ or $\mathrm{N}$ does not appear to 

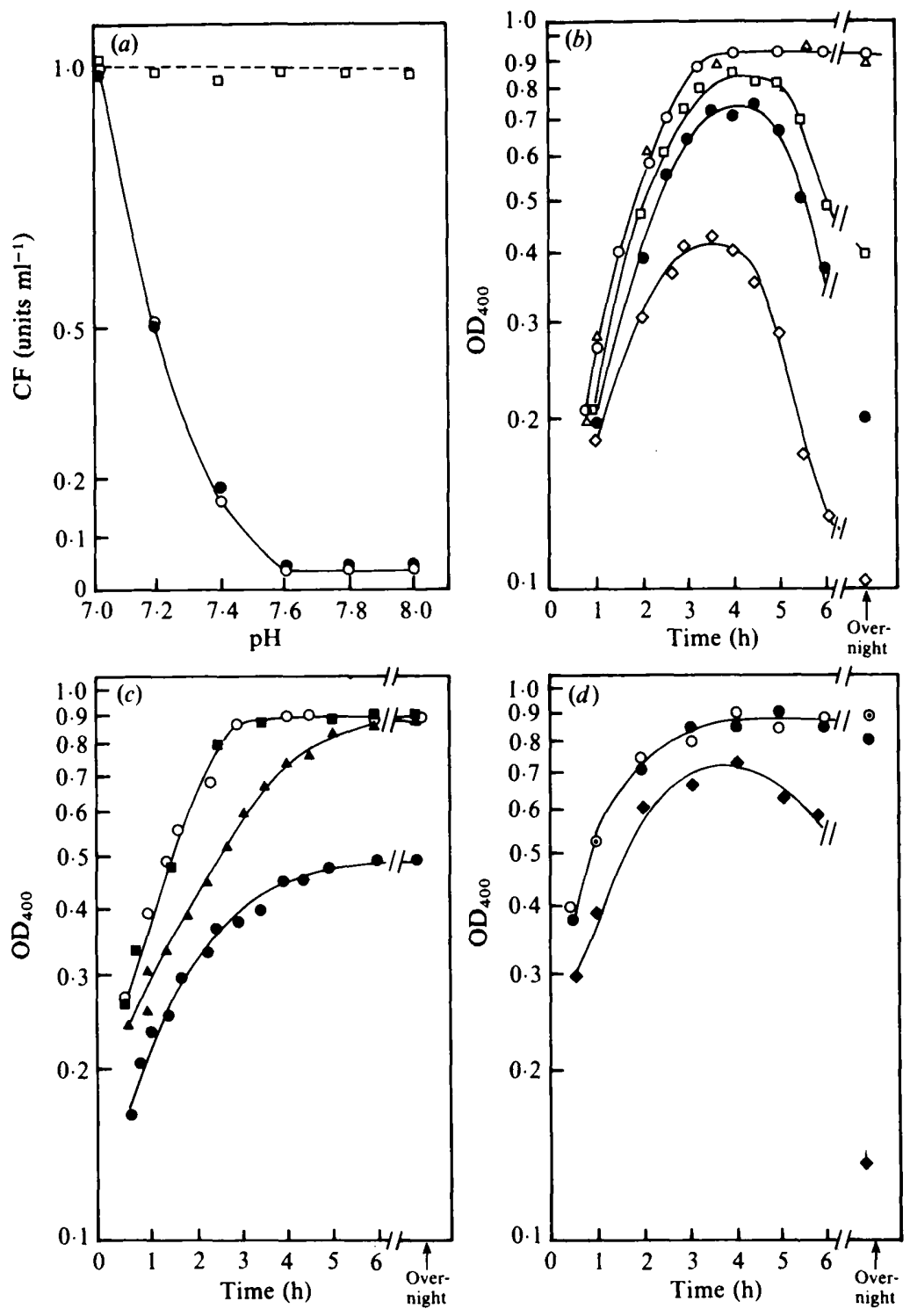

Fig. 3. CF-induced competence and culture lysis. (a) $\mathrm{CF}$ requirement for competence induction: effect of external pH. Tester cells of strains $\mathrm{Cp} 1000(\mathrm{O})$ and Cpl095 (O) were shifted to media of different $\mathrm{pH}$ values and stimulated by increasing amounts of $C F$. After $30 \mathrm{~min}$ incubation at $37^{\circ} \mathrm{C},\left[{ }^{3} \mathrm{H}\right] \mathrm{DNA}$ $\left(1 \mu \mathrm{g} \mathrm{ml}^{-1} ; 10^{5}\right.$ d.p.m. $\left.\mathrm{ml}^{-1}\right)$ was added and incubation was continued for $15 \mathrm{~min}$ at $32^{\circ} \mathrm{C}$. Acid-soluble radioactivity, used as a measure of competence, was quantified by liquid scintillation. The data plotted represent the $\mathrm{CF}$ concentration required, at each $\mathrm{pH}$, to obtain optimal competence, i.e. $5 \times 10^{3}$ d.p.m. per $0.1 \mathrm{ml}$ sample in the acid-soluble fraction and a transformation $\left(\right.$ Rif $\left.^{\mathrm{R}}\right)$ frequency between 1 and $5 \%$. A culture of strain Cp1322 ( $\square$ ) was similarly treated. (b) $\mathrm{CF}$ activation of culture lysis. Cultures of strain Cpl000 were started in $1.5 \mathrm{mM}^{-\mathrm{Ca}^{2}}{ }^{2+}$ media at $\mathrm{pH} 7$ (open symbols) and $\mathrm{pH} 8$ (filled symbols). Various amounts of CF were added at time zero of incubation and the optical density was monitored at intervals.

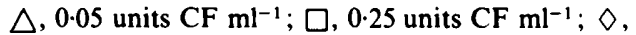
1 unit $\mathrm{CF} \mathrm{ml} \mathrm{m}^{-1} ; \bigcirc \bigcirc$, no addition. (c) Cultures of strain $\mathrm{Cp} 1095$ were started in media at $\mathrm{pH} 8$ containing $1.5 \mathrm{mM}-\mathrm{Ca}^{2+}$ (filled symbols) or $0.2 \mathrm{mM}$ $\mathrm{Ca}^{2+}$ (open symbols). Various amounts of $\mathrm{CF}$ were added at time zero and growth was monitored. $\boldsymbol{\Delta}$, 0.05 units $\mathrm{CF} \mathrm{ml} \mathrm{ml}^{-1} ; \bigcirc 0,0.5$ units $\mathrm{CF} \mathrm{ml} \mathrm{m}^{-1} ; \mathbf{0}$, growth at $\mathrm{pH} 8$ with $\mathrm{CF}$-free extract from strain Cp1322. (d) Cultures of strain Cpl 322 were started at $\mathrm{pH}$ 8. Various amounts of CF were added at time zero and growth was monitored. 0.5 units $C F$

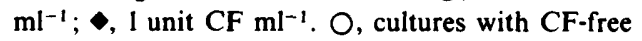
extract from strain Cpl 322 .

explain the $\mathrm{Ca}^{2+}$ response. Results in Fig. 4(a) show that addition of homologous or heterologous DNA $\left(1 \mu \mathrm{g} \mathrm{ml}^{-1}\right)$ prevented the cultures from lysing. In these cultures, competence development was not altered by DNA (data not shown). In contrast, neither polyphosphate nor tRNA prevented lysis (Fig. 4a), suggesting that the protective effect of DNA is not caused merely by its global negative charge. Strain $\mathrm{Cp} 1209$, deficient in DNA transport, which develops a normal competence pattern with regard to its nuclease activation or its gene regulation (Morrison et al., 1983), lysed even in DNAsupplemented medium (Fig. $4 b$ ). It is possible that the shift in the lysis profile of Cp1209, when grown in DNAcontaining medium (Fig. $4 b$ ), corresponds to a partial protection resulting from its residual transport activity, estimated at 0.5 to $1 \%$ of the wild-type activity (data not

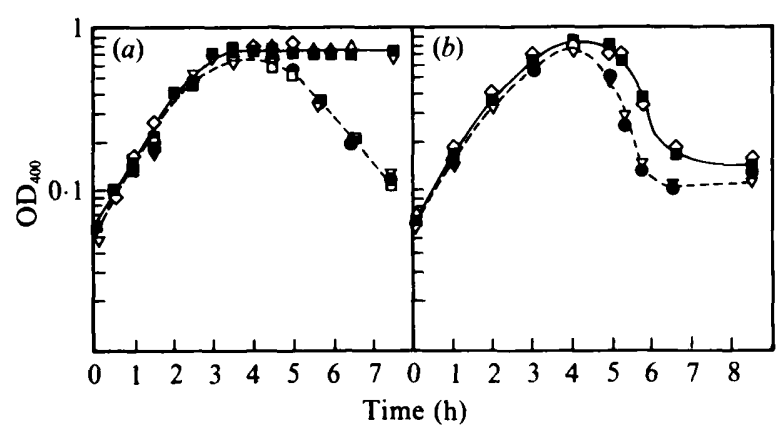

Fig. 4. Inhibition of lysis by DNA uptake. Tester cells from strains Cp1000 (a) and Cpl209 (b) were incubated at $37^{\circ} \mathrm{C}$ in media containing CF ( 0.7 units $\left.\mathrm{ml}^{-1}\right)$ and DNA $\left(1 \mu \mathrm{g} \mathrm{m}^{-1}\right)$ (solid line) from either $S$. pneumoniae $(\diamond)$ or salmon sperm $(\mathbb{C})$, or (dashed line) $1 \mu \mathrm{g}$ tRNA $\mathrm{ml}^{-1}(\nabla)$, or $1 \mu \mathrm{m}$ polytriphosphate $\mathrm{ml}^{-1}(\square)$. Controls with no addition. Growth was monitored as described in Fig. 3. 


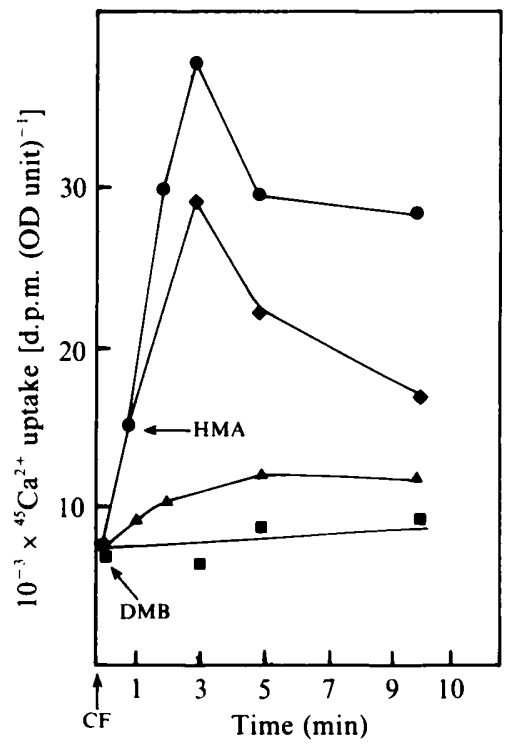

Fig. 5. Modulation of ${ }^{45} \mathrm{Ca}^{2+}$ transport by $\mathrm{CF}$ extracts: effect of amilorides. Tester cells from strain $\mathrm{Cpl} 1000$ were transferred into competence medium $\left[1.5 \mathrm{mM}-\mathrm{CaCl}_{2} ; 1 \mu \mathrm{Ci}(37 \mathrm{kBq}){ }^{45} \mathrm{Ca}^{2+} \mathrm{ml}^{-1}\right]$. The suspension was divided into four aliquots. Three were supplemented with $\mathrm{CF}\left(0.05\right.$ units $\left.\mathrm{ml}^{-1}\right)$ and $5 \mu \mathrm{M}-\mathrm{HMA}(\bullet)$ or $5 \mu \mathrm{M}-\mathrm{DMB}(\square)$ was added at the times indicated, followed by incubation at $37^{\circ} \mathrm{C}$. , No additions. The filters were rinsed with medium containing $\mathrm{CaCl}_{2}$ $\left(0.5 \mathrm{mg} \mathrm{ml}^{-1}\right)$ and the radioactivity retained by the bacteria was determined at intervals by filtration assays. $\mathbf{\Delta}$, Cultures treated with CF-free extracts from strain Cp1322.

shown). In any case, these results indicate that DNA uptake is necessary to prevent lysis of cultures which have passed through a competence cycle.

\section{Ion fluxes and competence induction}

During competence induction fluctuation of the $\mathrm{Na}^{+}$ content of the bacteria was observed and it was noted that their $\mathrm{K}^{+}$levels did not change (Lopez et al., 1989). Measurement of the ${ }^{45} \mathrm{Ca}^{2+}$ flux in a CF-stimulated culture showed a transient increase in ${ }^{45} \mathrm{Ca}^{2+}$ retained by the cells compared to the control (Fig. 5). Treatment of cells with amiloride derivatives resulted in total inhibition of $\mathrm{Ca}^{2+}$ transport by DMB (Fig. 5) while HMA lowered $\mathrm{Ca}^{2+}$ uptake by $20 \%$ of the control. Measurements of the influx velocity, $V$, after $15 \mathrm{~s}$ corroborate these observations (data not shown). DMB has been described as an inhibitor of $\mathrm{Ca}^{2+}$ porters in eukaryotes (Kaczorowski et al., 1985; Simchowitz \& Cragoe, 1986). Interestingly, DMB prevented culture lysis (Fig. $1 b$ ), and was a strong inhibitor of competence induction, but under the same conditions it allowed full competence expression of pre-induced cultures (Table 1). Such an inhibition of competence induction and of culture lysis
Table 1. Effect of amilorides on competence induction and competence expression in strain Cp1000

The $\left[{ }^{3} \mathrm{H}\right] \mathrm{DNA}\left(1 \mu \mathrm{g} \mathrm{m} \mathrm{l}^{-1}, 15000 \mathrm{~d} . \mathrm{p} . \mathrm{m}^{\mathrm{m}} \mathrm{ml}^{-1}\right)$ degrading activity of the cultures was taken as the competence indicator. Each assay was performed in triplicate and the experiment was repeated twice. The $100 \%$ value corresponds to 10000 d.p.m. ml ${ }^{-1} \pm 10 \%$. Amiloride derivatives were added at time zero of induction $(a)$ or to pre-induced cultures during expression $(b)$.

\begin{tabular}{ccc}
\hline \hline $\begin{array}{c}\text { Compound } \\
\text { added }\end{array}$ & $\begin{array}{c}(a) \\
\text { Induction } \\
(\% \text { control })\end{array}$ & $\begin{array}{c}(b) \\
\text { Expression } \\
(\% \text { control) }\end{array}$ \\
\hline $\begin{array}{c}\text { None (control) } \\
\text { Amiloride } \\
1-10 \mu \mathrm{M}\end{array}$ & 100 & 100 \\
HMA & 100 & 100 \\
$1 \mu \mathrm{M}$ & 100 & 100 \\
$5 \mu \mathrm{M}$ & 80 & 100 \\
DMB & & \\
$1 \mu \mathrm{M}$ & 70 & 100 \\
$5 \mu \mathrm{M}$ & 20 & 100 \\
\hline \hline
\end{tabular}

Table 2. Stimulation of competence induction in strain Cp1000, at low $\mathrm{Ca}^{2+}$ concentrations, by the $\mathrm{Ca}^{2+}$ ionophore A23187

Induction was obtained in alkaline media with $\mathrm{Ca}^{2+}$ concentrations adjusted as indicated, with or without the $\mathrm{Ca}^{2+}$ ionophore A23187. $\left[{ }^{3} \mathrm{H}\right] \mathrm{DNA}\left(1 \mu \mathrm{g} \mathrm{ml}{ }^{-1}, 15000\right.$ d.p.m. $\left.\mathrm{ml}^{-1}\right)$ bearing the ery32 genetic marker was routinely used. The standard deviation of DNA degradation and DNA transport measurements, performed in triplicate, never exceeded $10 \%$; it was $5 \%$ for the estimation of transformants.

\begin{tabular}{|c|c|c|c|}
\hline $\begin{array}{c}\mathrm{Ca}^{2+} \\
\text { added }\end{array}$ & $\begin{array}{c}\text { DNA } \\
\text { degradation } \\
\text { (d.p.m. } \mathrm{ml}^{-1} \text { ) }\end{array}$ & $\begin{array}{c}\text { DNA } \\
\text { transport } \\
\text { (d.p.m. } \mathrm{ml}^{-1} \text { ) }\end{array}$ & $\begin{array}{c}\text { Rif } \\
\text { transformants } \\
\text { (percentage } \\
\text { of culture) }\end{array}$ \\
\hline $\begin{array}{c}1.2 \mathrm{mM}^{-\mathrm{CaCl}_{2}} \\
0.4 \mathrm{~mm}-\mathrm{CaCl}_{2} \\
0.4 \mathrm{mM}^{-\mathrm{CaCl}_{2}}+ \\
1 \mu \mathrm{M}-\mathrm{A} 23187\end{array}$ & $\begin{array}{r}9120 \\
4700 \\
11030\end{array}$ & $\begin{array}{l}3720 \\
1830 \\
4470\end{array}$ & $\begin{array}{r}17 \% \\
8 \% \\
20 \%\end{array}$ \\
\hline
\end{tabular}

was not observed in the presence of the other derivatives (Table 1 and Fig. $1 b$ ). It is likely that the DMB-sensitive function is involved in competence induction as well as in triggering culture lysis. As DMB interferes with $\mathrm{Ca}^{2+}$ transport, $\mathrm{Ca}^{2+}$ porter(s) might constitute(s) the drug target. Therefore, $\mathrm{Ca}^{2+}$ circulation is probably a key event in competence induction and in triggering lysis of the bacteria. Indeed, using the $\mathrm{Ca}^{2+}$ ionophore A23187 it was possible to obtain, in the wild-type strain, full induction at a suboptimal $\mathrm{Ca}^{2+}$ concentration (Table 2 ). This suggests that $\mathrm{Ca}^{2+}$ influx is a determinant in the regulation of competence induction. A similar effect was not observed in strain Cp1322 (data not shown); therefore, the $\mathrm{Ca}^{2+}$ ionophore cannot complement the 
defect in CF production. In addition, CF did not lower the $\mathrm{Ca}^{2+}$ requirement for induction in the wild-type strain (Fig. 2a) as does A23187 (Table 2). CF probably does not act simply as a $\mathrm{Ca}^{2+}$ ionophore.

\section{Discussion}

In $S$. pneumoniae, $\mathrm{Ca}^{2+}$ is an obligatory cation that is required at a threshold concentration of $0.15 \mathrm{~mm}$ (Fig. 1a). It is noteworthy that high $\mathrm{Ca}^{2+}$ triggers both a permissive state for DNA uptake at competence and for DNA liberation during lysis. Inhibition of $\mathrm{Ca}^{2+}$ uptake by DMB (Fig. 5) can be correlated with inhibition of both lysis (Fig. $1 b$ ) and competence induction (Table 1), suggesting that $\mathrm{Ca}^{2+}$ transport is the determinant process. The involvement of $\mathrm{Ca}^{2+}$ at the onset of sporulation in B. subtilis (Murrell, 1967) and in competence induction in $S$. pneumoniae (Fox \& Hotchkiss, 1957) have already been described. However, some media allowing competence development contain less than $1 \mathrm{mM}-\mathrm{Ca}^{2+}$, but are supplemented with a mixture of divalent cations (Tomasz \& Hotchkiss, 1964). In these media, competence develops when the cultures reach an $\mathrm{OD}_{400}$ of 0.3 to 0.4 , while competence was attained at an $\mathrm{OD}_{400}$ about 0.05 to 0.1 in the medium used for this study. This suggests that another set of growth parameters might trigger competence. In any case, in our system conditions that do not allow competence development, such as absence of $C F$ production in the com mutant Cp1322 (Fig. 3d) and neutral pH (Fig. $1 a$ ) do not allow $\mathrm{Ca}^{2+}$-induced lysis.

Complementation of mutant $\mathrm{Cp} 1322$ and cultures of the wild-type strain grown at neutral $\mathrm{pH}$ with exogenous CF restores both competence induction (Fig. $3 a$ ) and lysis (Fig. $3 b, d$ ). CF extract could not complement the lysis defect of the lyt mutant. It is thus unlikely that the extract was contaminated by a lytic activity. So far neither $\mathrm{Ca}^{2+}$ nor alkaline $\mathrm{pH}$ have been described as activators for the autolysin (Höltje \& Tomasz, 1976; Trombe, 1981). However, $\mathrm{pH}$-dependent lysis activation involving the bacterial autolysins has been described in $\beta$-lactam-treated cultures of $B$. subtilis and $S$. pneumoniae (Lopez et al., 1976, 1989, 1990). Interestingly, the C medium used for bacterial growth in those experiments was one of the classical competence media (Lacks \& Hotchkiss 1960). Although competence development has not been checked in those works, it is interesting to point out that culture lysis was avoided by protease addition, which is well known to block competence induction also (Lacks \& Greenberg, 1973). It is possible that several growth conditions might trigger culture lysis in a $\mathrm{pH}$ dependent manner. This might be the consequence of perturbation of peptidoglycan biosynthesis. On the other hand, the leader region lying within the lyt promoter (Diaz \& Garcia, 1990) might somehow contribute to regulation of lyt expression in response to deleterious growth conditions. Nevertheless, our findings support strongly the hypothesis that competence and lysis constitute responses to $\mathrm{Ca}^{2+}$ stress, regulated by $\mathrm{CF}$ or by different activators, produced in and co-purified from the same cultures.

In $\mathrm{lyt}^{+}$cultures, lysis is overcome in the presence of exogenous DNA if the bacteria are genetically capable of DNA uptake (Fig. $4 a, b$ ). Homologous or heterologous DNA are equivalent for lysis protection (Fig. 4a). After uptake, the fate of these two substrates is quite different but in the end, both processes lead to a replenishment of the nucleotide pool. Pneumococcal DNA is integrated by homologous recombination resulting in the local replacement of one strand of the recipient molecule by the transforming strand. The parental strand is then degraded and the nucleotides are used for de novo DNA synthesis (Lacks et al., 1967). Heterologous DNA is degraded by endonucleases and enters the nucleotide pool. Thus, DNA uptake by competent bacteria might be looked on as a process that allows nucleotide feeding. A dramatic metabolic upshift triggered by $\mathrm{Ca}^{2+}$ and regulated by $\mathrm{CF}$ occurs at competence. Stimulation of glycolysis associated with an elevation of the ATP pool, a cytoplasmic alkalinization (Lopez et al., 1989) and synthesis of the lipid polymer poly $(\beta$-hydroxybutyrate) (Reusch \& Sadoff, 1983; Clavé et al., 1989) have been described. If one branch of the metabolic network is not activated in a concerted manner and becomes limiting, growth might, then, become unbalanced. DNA uptake prevents lysis of cultures which have passed through a competence cycle. Nucleotides might represent the limiting factor in cultures growing in high $\mathrm{Ca}^{2+}$ media. As an hypothesis, we propose that activation of DNA uptake at competence might be an homeostatic regulation for the restoration of balanced growth conditions.

The natural environment of $S$. pneumoniae is body fluids in which the $\mathrm{Ca}^{2+}$ concentration is around $1.5 \mathrm{mM}$, the concentration at which competence and lysis are obtained under laboratory conditions. Interestingly, comA (Morrison et al., 1984; Chandler \& Morrison, 1988), a gene belonging to the com locus, whose disruption prevents $\mathrm{CF}$ production, contains consensus sequences characteristic of the superfamily of ATPdependent bacterial transporters (Hui \& Morrison, 1991). The ComA primary structure, derived from the nucleic acid sequence of the com $A$ gene, shows a strong homology with HlyB, which is involved in the export of the bacterial toxin haemolysin in $E$. coli (Koronakis $e t$ al., 1988). By analogy, it has been proposed that the com locus contains an operon encoding the synthesis and excretion of CF. CF might be a molecule allowing a cycle 
of consecutive lysis and transformations, resulting in cross-feeding within natural co-cultivated subpopulations. Indeed, under laboratory conditions, successive competence waves can be observed in the same culture (Chen \& Morrison, 1987). Genetic exchanges at competence might be part of a more general cross-feeding event. In this highly regulated process, $\mathrm{Ca}^{2+}$ transport via a DMB-sensitive function plays a central role (Fig. 5 , Table 1).

This work was supported by Université P. Sabatier and Centre National de la Recherche Scientifique LP008201. Corinne Clavé was supported by a grant from Ministère de la recherche et de la Technologie and Jean-Michel Manias was a graduate student.

We thank Dr Diane Stassi for helpful discussions during preparation and editing of the manuscript. Strain GP95 was kindly provided by $\mathrm{Dr}$ Gianni Pozzi, Universita di Verona, Verona, Italy.

\section{References}

Ambudkar, S. V., LynN, A. R., Maloney, P. C. \& Rosen, B. P. (1986). Reconstitution of ATP-dependent calcium transport from streptococci. Journal of Biological Chemistry 261, 15596-15600.

Chandler, M. S. \& Morrison, D. A. (1988). Identification of two proteins encoded by com, a competence control locus of Streptococcus pneumoniae. Journal of Bacteriology 170, 3136-3141.

CHEN, J. D. \& MorRison, D. A. (1987). Modulation of competence for genetic transformation in Streptococcus pneumoniae. Journal of General Microbiology 133, 1959-1967.

ClavÉ, C. (1988). Flux ioniques et energetique cellulaire au cours de l'induction de la competence chez Streptococcus pneumoniae, leur implication dans le transport de l'ADN. Doctorat d'Université, Université Paul Sabatier, Toulouse, France.

Clavé, C. \& Trombe, M. C. (1989). Intracellular pH and ATP involvement in DNA uptake by Streptococcus pneumoniae competent for genetic transformation. FEMS Microbiology Letters 65, 113-118.

Clavé, C., Morrison, D. A. \& Trombe, M. C. (1987). Is DNA transport driven by the proton electrochemical potential difference in the naturally transformable bacteria Streptococcus pneumoniae? Bioelectrochemistry and Bioenergetics 17, 269-276.

Clavé, C., Martin, F. \& Trombe, M. C. (1989). DNA uptake in Streptococcus pneumoniae : an insight into energetics and mechanism. In Genetic Transformation and Expression, pp. 27-40. Edited by L. O. Butler, C. Harwood \& B. E. B. Moseley. Andover: Intercept.

DIAZ, E. \& GARCIA, J. L. (1990). Characterization of the transcription unit encoding the major pneumococcal autolysin. Gene 90, 157-162.

DuBnaU, D. (1991). The regulation of genetic competence in Bacillus subtillis. Molecular Microbiology 5, 11-18.

Falah, A. M. S., Bhatnagar, R., Bhatnagar, N., Singh, Y., Sidhu, G. S., Murthy, P. S. \& Venkitasubramanian, T. A. (1988). On the presence of calmodulin-like protein in mycobacteria. FEMS Microbiology Letters 56, 89-94.

Fox, M. S. \& Hotchkiss, R. D. (1957). Initiation of bacterial transformation. Nature, London 179, 1322-1325.

Fry, I. J., Villa, L., Kuehn, G. D. \& Hageman, J. H. (1986). Calmodulin-like protein from Bacillus subtilis. Biochemical and Biophysical Research Communications 134, 212-217.

HöltJE, J. V. \& TOMASZ, A. (1976). Purification of the pneumococcal $N$-acetylmuramyl-L-alanine amidase to biochemical homogeneity. Journal of Biological Chemistry 251, 4199-4207.

HUI, F. M. \& MORRISON, D. A. (1991). Genetic transformation in Streptococcus pneumoniae : nucleotide sequence analysis shows $\operatorname{com} A$, a gene required for competence induction, to be a member of the bacterial ATP-dependent transport protein family. Journal of Bacteriology 173, 372-382.
INOUYE, S., Franceschinl, T. \& INOUYE, M. (1983). Structural similarities between the development-specific protein $S$ from a Gram-negative bacterium Myxococcus xanthus and calmodulin. Proceedings of the National Academy of Sciences of the United States of America 80, 6829-6833.

Kaczorowski, G. J., Barros, F., Dethmers, J. K. \& Trumble, M. J. (1985). Inhibition of $\mathrm{Na}^{+} / \mathrm{Ca}^{2+}$ exchange in pituitary membrane vesicles by analogues of amiloride. Biochemistry 24, 1394-1403.

Kobayashi, H., Van Brunt, J., \& Harold, F. M. (1978). ATP-linked calcium transport in cells and membrane vesicles of Streptococcus faecalis. Journal of Biological Chemistry 253, 2085-2092.

Koronakis, V. M., Cross, M., Senior, B., Koronakis, E. \& Hughes, C. (1988). Comparison of the haemolysin secretion protein HlyB from Proteus vulgaris and $E$. coli; site-directed mutagenesis causing impairment of export function. Molecular and General Genetics 213, 551-555.

LACKS, S. A. (1977). Binding and entry of DNA in pneumococcal transformation. In Modern Trends in Bacterial Transformation and Transfection, pp. 35-44. Edited by A. Portoles, R. Lopez \& M. Espinoza. Amsterdam: Elsevier/North Holland.

LACKS, S. A. \& Greenberg, B. (1973). Competence for DNA uptake and deoxyribonuclease action external to cells in the genetic transformation of Diplococcus pneumoniae. Journal of Bacteriology $114,152-163$.

LACKS, S. \& HotChKISS, R. D. (1960). A study of the genetic material determining an enzyme activity in pneumococcus. Biochimica and Biophysica Acta 39, 508-517.

LACKS, S. A. \& NeUberger, M. (1975). Membrane location of a deoxyribonuclease implicated in the genetic transformation of Diplococcus pneumoniae: Journal of Bacteriology 124, 1321-1329.

LaCKS, S., Greenberg, B. \& CARLSON, K. (1967). Fate of donor DNA in pneumococcal transformation. Journal of Molecular Biology 29, $327-347$.

LeONARD, C. G. \& Cole, R. M. (1972). Purification and properties of streptococcal competence factor isolated from chemically defined medium. Journal of Bacteriology 110, 273-280.

Lerman, L. S. \& TOLMACH, L. J. (1957). Genetic transformation. I. Cellular incorporation of DNA accompanying transformation in pneumococcus. Biochimica and Biophysica Acta 26, 68-82.

Lopez, R., Ronda-lain, C., Tapia, A., Waks, S. B. \& Tomasz, A. (1976). Suppression of the lytic and bactericidal effects of cell wallinhibitory antibiotics. Antimicrobial Agents and Chemotherapy 10, $697-706$.

Lopez, A., Clavé, C., Capeyrou, R., Lafontan, V. \& Trombe, M. C. (1989). Ionic and energetic changes at competence in the naturally transformable bacterium Streptococcus pneumoniae. Journal of General Microbiology 135, 2189-2197.

Lopez, R., Ronda, C. \& Garcia, E. (1990). Autolysins are directly involved in the bactericidal effect caused by penicillin in wild type and in tolerant pneumococci. FEMS Microbiology Letters 66, 317322.

LOVE, P. E. \& YASBIN, R. E. (1986). Induction of the Bacillus subtilis RecA protein. Proceedings of the National Academy of Sciences of the United States of America 83, 5204-5208.

Morrison, D. A. \& BaKer, F. M. (1979). Competence for genetic transformation in pneumococcus depends on synthesis of a small set of proteins. Nature, London 282, 215-217.

Morrison, D. A., Lacks, S. A., Guild, W. R. \& Hageman, J. M. (1983). Isolation and characterization of three new classes of transformation-deficient mutants of Streptococcus pneumoniae that are defective in DNA transport and genetic recombination. Journal of Bacteriology 156, 281-290.

Morrison, D. A., Trombe, M. C., Hayden, M. K., Waszack, G. A. \& CHEN, J. D. (1984). Isolation of transformation-deficient Streptococcus pneumoniae mutants defective in control of competence, using insertion-duplication mutagenesis with the erythromycin resistance determinant pAMB1. Journal of Bacteriology 159, 870-876.

MURRELL, W. G. (1967). The biochemistry of the bacterial endospore. Advances in Microbial Physiology 1, 133-251.

NAVA, G., GALIS, A. \& BeISER, S. M. (1963). Bacterial transformation: an antigen specific for competent pneumococci. Nature, London 197, 903-904. 
Pakula, R. \& Walczak, W. (1963). On the nature of competence activator of transformable streptococci. Journal of General Microbiology 31, 125-133.

Raina, J. L. \& Ravin, A. W. (1980). Switches in macromolecular synthesis during induction of competence for transformation of Streptococcus sanguis. Proceedings of the National Academy of Sciences of the United States of America 77, 6062-6066.

REUSCH, R. N. \& SADOFF, H. L. (1983). D-(-)-Poly- $\beta$-hydroxybutyrate in membranes of genetically competent bacteria. Journal of Bacteriology 156, 778-788.

Rosen, B. P. (1987). Bacterial calcium transport. Biochimica et Biophysica Acta 906, 101-110.

Sanchez-Puelles, J. M., Ronda, J. M., Garcia, C., Mendez, E., GarCiA, E., GarCIA, J. L. \& LoPEZ, R. (1986). A new peptidoglycan hydrolase in Streptococcus pneumoniae. FEMS Microbiology Letters $35,163-166$.

SeTo, H. \& Tomasz, A. (1974). Early stages in DNA binding and uptake during genetic transformation of streptococci. Proceedings of the National Academy of Sciences of the United States of America 71, 1493-1498.

Seto, H. \& Tomasz, A. (1976). Calcium-requiring step in the uptake of deoxyribonucleic acid molecules through the surface of competent pneumococci. Journal of Bacteriology 126, 1113-1118.

Simchowitz, L. \& CraGoe, E. J., JR (1986). Inhibition of chemotactic factor-activated $\mathrm{Na}^{+} / \mathrm{H}^{+}$exchange in human neutrophils by analogues of amilorides: structure-activity relationships in the amiloride series. Molecular Pharmacology 30, 112-120.

Swan, D. G., Cortes, J., Hale, R. S. \& Leadlay, P. F. (1989) Cloning, characterization and heterologous expression of the Saccharopolyspora erythraea gene encoding an EF-hand calciumbinding protein. Journal of Bacteriology 171, 5614-5619.
Swan, D. G., Hale, R. S., Dhillon, N. \& Leadley, P. F. (1987). A bacterial calcium-binding protein homologous to calmodulin. Nature, London 329, 84-85.

TIRABY, G. \& Fox, M. S. (1973). Marker discrimination in transformation and mutation of Streptococcus pneumoniae. Proceedings of the National Academy of Sciences of the United States of America 70, 3541-3545.

Tomasz, A. \& Horchkiss, R. D. (1964). Regulation of the transformability of pneumococcal cultures by macromolecular cell products. Proceedings of the National Academy of Sciences of the United States of America 51, 480-487.

Tomasz, A., Moreillon, P. \& Pozzi, G. (1988). Insertional inactivation of the major autolysin of Streptococcus pneumoniae. Journal of Bacteriology 170, 5931-5934.

Trombe, M. С. (1981). Caractérisation de mutants de résistance à l'améthoptérine chez Streptococcus pneumoniae; altération du potentiel transmembranaire. Mise en evidence d'une cible membranaire pour l'améthopterine. Doctorat D'état, Université Paul Sabatier, Toulouse, France.

Trombe, M. C. (1983). Alteration du transport actif des acides aminés au moment de la competence chez Streptococcus pneumoniae. Comptes Rendus de l'Academie des Sciences. Paris. Sciences de la Vie 294, 42-44.

Trombe, M. C. Lanéelle, G. \& Sicard, A. M. (1984). Characterization of a Streptococcus pneumoniae mutant with altered electric transmembrane potential. Journal of Bacteriology 158, 11091114.

ZIEGLER, R. \& TOMASZ, A. (1970). Binding of the competence factor to receptors in the spheroplast membrane of streptococci. Biochemical and Biophysical Research Communications 41, 1342-1349. 